\title{
Planning and Brand Communication for Ice-snow Sports Tourism Products in the Arctic Village of Mohe County
}

\author{
Wei Gao, Xiaoguo Chang \\ Harbin Finance University, Harbin, Heilongjiang, China
}

\begin{abstract}
Locating in the northernmost region of China, the Arctic Village of Mohe County is enlisted as one of the most charming tourist attractions of China for the unique resources and landscapes, such as "northernmost location", magical astronomical phenomena and arctic ice-snow. However, it failed to explore domestic and foreign markets yet due to the poor promotion of government, thus resulting in the low consumer brand recognition. Combining with existing tourism resources in the Arctic Village, this study proposed an appropriate product planning based on the national promotion of "ice-snow tourism". Meanwhile, great efforts were made to the propagation and publicity of the brand to improve brand influence of the Arctic Village. The ice-snow resources in surrounding region were integrated to promote the tourism development in the whole Heilongjiang Province.
\end{abstract}

Keywords:Arctic Village, ice-snow tourism, product planning, brand communication

\section{I.Overview of related theories}

\subsection{Elaboration of Concept of Ice-Snow Sports Tourism}

Currently, no definition on the concept of ice-snow sports tourism has been proposed yet. The foreign scholar Hall proposed in a relevant study in 1992 that "sports tourism shall be a non-commercial tourism activity that participates or watches sports activities, but is beyond the daily life range." Li Guang and Li Yanling, two Chinese scholars, declared that "ice-snow tourism refers to various athletic activities based on ice and snow resources and the sum of tourism destinations, tourism society and tourism enterprises." Among most opinions of Chinese and foreign scholars, ice-snow sports tourism is a branch of sports tourism and it has characteristics of both sports tourism and ice-snow tourism. Combining with opinions of Chinese and foreign scholars, ice-snow sports tourism can be summarized as a spontaneous tourism activity that people gain physical and psychological pleasures by participating in ice-snow sports or appreciating ice-snow sports competitions and shows. It meets ice-snow tourism demands of different tourists ${ }^{[1]}$.

\subsection{Brank Marketing}

Brand marketing is a process that helps target consumers to form cognition to a brand and a product through marketing. Briefly, brand marketing is to give consumers a deep impression of unique images of a product or a service through some means. Brand marketing is a marketing strategy and process that create value recognitions of a product in inner hearts of users through propagation on its quality, culture and uniqueness according to consumers' demands, finally forming brand effects.

The key of brand marketing for tourism cities lies in searching a core value of the brand that has different personalities and can affect inner feeling of consumers for the city to make it competitive among homogeneous tourism cities $^{[2]}$.

\section{II.Development Status of Ice-Snow Sports Tourism Industry in Heilongjiang Province}

Heilongjiang Province is in the most north region of Northeast China and there are plains, valleys and high mountains. Heilongjiang Province witnesses a long winter, resulting in the long snowing period. Compared to other

ISSN: 0010-8189

C CONVERTER 2021

Www.converter-magazine.info 
regions, Heilongjiang Province has heavy and high-quality snows. The good ice-snow and landscape resources lay foundations for the development of ice-snow sports tourism industry in Heilongjiang Province. Through an investigation, Heilongjiang Province has nearly 200 ski runs and more than 120 ropeways. Heilongjiang Province once was titled as one of regions which are most appropriate to develop ice-snow sports tourism industry in China. Subsequently, Heilongjiang Province won titles of "World Ice-snow Tourism Attraction", "International Skiing Tourism Place", etc. Due to the high-quality ice-snow resources, Heilongjiang Province has achieved rapid development as an ice-snow sports tourism brand with regional characteristics and certain scale has been formed significantly ${ }^{[3]}$.

In Heilongjiang Province, the ice-snow sports tourism resources are centered at Harbin and radiate to other tourismregions. Harbin has been known as the "ice city" and the main ice-snow tourism resources include the Ice-snow World, Sun Island Snow Exposition, Happy Ice-snow World in the Hulan River Estuary Wetland, Wanda World of Ice Lamps and dozens of hot springs in snowy regions and ski resorts. Other ice-snow tourism resources cover the Yabuli, Snow Town and Snow Valley in the whole tourist area of Zhuangguangcai Mountain, an Arctic Village in the Greater Khingan Mountains areas which are characteristic of arctic lights, Beiyin Spring, Santa Claus House and Santa Claus Post Office, Taoshan Hunting Ground and Kuerbin Rime in the Lesser Khingan Mountains, Lindian Hot Spring in theDorbod Mongol Autonomous County of Daqing, etc. ${ }^{[4]}$

Heilongjiang Province provides diversified economic entities of platforms for the ice-snow sports tourism, such as indoor and outdoor ski resorts and indoor and outdoor skating rinks. These ski resorts and skating rinks are the most important guarantee to ice-snow sports tourism. According to an associated field investigation, Heilongjiang Province has more than $40 \mathrm{ski}$ resorts for ice-snow sports tourism. As you can see from the table 1,there are 16 snowfields above Grade $\mathrm{S}$ in Harbin.Moreover, there are relatively abundant ice-snow resources ${ }^{[5]}$.

TABLE 1 Harbin S class and above Ski Resort

\begin{tabular}{|l|l|l|l|}
\hline number & grade & Name of ski resort & address \\
\hline 1 & SSSSS & Yabuli Ski Resort,Heilongjiang Province & Yabuli Town, Shangzhi City, Harbin \\
\hline 2 & SSSSS & New Moat Yabuli Sunshine Resort Ski resort & Yabuli Town, Shangzhi City, Harbin \\
\hline 3 & SSSSS & Maori Mountain Ski Resort & Shaershan Town, Harbin City \\
\hline 4 & SSSSS & $\begin{array}{l}\text { Harbin Jihua Changshou Mountain Ski } \\
\text { Resort }\end{array}$ & $\begin{array}{l}\text { Harbin Binxian Longevity National Forest } \\
\text { Park }\end{array}$ \\
\hline 5 & SSS & Erlongshan Longzhu Ski Resort & Erlongshan, Shangzhi City, Harbin \\
\hline 6 & SSS & Hirayama Deer Ski Resort & Pingshan Town, Acheng City, Harbin \\
\hline 7 & SSS & Huatian Ujmi Ski Resort & Harbin Shangzhi City Wujimi \\
\hline 8 & SSS & Shangjing International Ski Resort & $\begin{array}{l}\text { Moban Village, Yuquan Town, Acheng } \\
\text { District, Harbin }\end{array}$ \\
\hline 9 & SSS & Yabuli Haohanling Ski resort & Yabuli Town, Shangzhi City, Harbin \\
\hline 10 & SS & Harbin Mingdu Ski Resort & 215 Haping Road, Harbin Power Zone \\
\hline 11 & SS & East Blue Sky Ski Club ski resort & Acheng, Harbin \\
\hline 12 & SS & Tiger Mountain Forest Park ski resort & Yuquan Town, Acheng, Harbin \\
\hline 13 & SS & Yuquan hunting ground ski resort & $\begin{array}{l}\text { Yuquan Town, Acheng, Harbin } \\
\text { Harbin Shengda Tourism Co., LTD. Ski }\end{array}$ \\
\hline 14 & SS & Harbin. \\
\hline 15 & S & $\begin{array}{l}\text { Moon Bay Ski Resort } \\
\text { resort }\end{array}$ & $\begin{array}{l}\text { Yueliangwan Development Zone, Jiangbei, } \\
\text { Harbin }\end{array}$ \\
\hline
\end{tabular}

Source: Harbin Statistics Bureau

As a great province of ice-snow resources, Heilongjiang Province has considerable influences in the sports competition field. Heilongjiang Province has held many international and national ice-snow sports competitions, such as the 24th Winter Olympics for World University Students, the National Freestyle Slalom Chase Championship of 2018-2019, the National Snowboarding Chase Championship of 2018-2019 and National Mixed Doubles Curling Championship. In 2017, the Heilongjiang Kunlun Hongxing ice hockey team was founded and the World-class Ice Hockey Competition ------ VHL League settled down in Heilongjiang Province. Moreover,

ISSN: 0010-8189

C CONVERTER 2021

www.converter-magazine.info 
Olympic champions, such as Wang Meng, Yang Yang, Wu Dajing, Zhang Kong, Shen Xue, Zhao Hongbo and Wang Bingyu, all grew up in Heilongjiang Province and strengthened influences of ice-snow sports tourism of the province. The International Ice and Snow Festival of Harbin, International Skiing Festival of Heilongjiang Province and "Ice-snow Activities for Millions of Teenagers" have generated huge promotion effect and ice-snow competitions have become a bright spot of ice-snow sports tourism in Heilongjiang Province.

There are also rich mass sports tourism projects in Heilongjiang Province, including mass skiing, skating and winter swimming projects. Moreover, Heilongjiang Province provides ice and snow entertainment activities. Ice entertainment activities have ice sledge by dogs, ice go-karting, ice slides, spinning top on ice, model show on ice, dancing on ice, and so on. Snow entertainment activities include snowmobile, snow football, snowball fight, etc. The ice-snow tourism project in the mass sports field has become an important competitive resource of the ice-snow sports tourism industry ${ }^{[6]}$.

We can see from Table 2, ice and snow sports tourism represented by Changchun, Shenyang, Beijing, Inner Mongolia and Xinjiang each has its own characteristics.

Internationally, it can be seen from Table 3 that Asian ice and snow tourism, represented by Japan and South Korea, has also begun to seize the Chinese market, and targeted tourism businesses and special promotional activities have been carried out.

TABLE 2 Analysis of domestic competitors in Harbin's development of ice and snow tourism

\begin{tabular}{|c|c|c|c|}
\hline $\begin{array}{l}\text { CLASS } \\
\text { IFY }\end{array}$ & $\begin{array}{l}\text { MAIN } \\
\text { COMPETITORS }\end{array}$ & ADVANTAGE & DISADVANTAGED \\
\hline \multirow{3}{*}{$\begin{array}{l}\text { A LINE } \\
\text { OF } \\
\text { BRAND }\end{array}$} & Shenyang & $\begin{array}{l}\text { 1. Excellent natural } \\
\text { environment }\end{array}$ & $\begin{array}{l}\text { 1. Low temperature, not suitable } \\
\text { for long-term outdoor activities }\end{array}$ \\
\hline & Yichun & 2. Domestic leading facilities & 2. Price is on the high side \\
\hline & Changchun & $\begin{array}{l}\text { 3. The competitive advantage of } \\
\text { industrial cluster } \\
\text { 4. Equipped with high, medium } \\
\text { and low ski slopes }\end{array}$ & 3. Remote location \\
\hline \multirow{4}{*}{$\begin{array}{l}\text { SECON } \\
\text { D-TIER } \\
\text { BRAN } \\
\text { DS }\end{array}$} & Shijiazhuang & $\begin{array}{l}\text { 1. Abundant natural and arts to } \\
\text { urism resources }\end{array}$ & $\begin{array}{l}\text { 1. Short ice age with poor } \\
\text { quality of snow }\end{array}$ \\
\hline & Beijing & 2. Convenient transportation & $\begin{array}{l}\text { The development advantage of } \\
\text { ice and snow sports tourism as } \\
\text { an auxiliary industry is not } \\
\text { obyious }\end{array}$ \\
\hline & Hohhot & 3. Complete related industries & \\
\hline & & $\begin{array}{l}\text { 4. The climate is relatively } \\
\text { favorable }\end{array}$ & \\
\hline THIRD & Tianjin & 1. Lower price strategy & $\begin{array}{l}\text { 1. Emerging industries are less } \\
\text { competitive }\end{array}$ \\
\hline $\begin{array}{l}- \text { LINE } \\
\text { BRAND } \\
\text { S }\end{array}$ & Chengdu & $\begin{array}{l}\text { 2. A variety of recreational } \\
\text { activities } \\
\text { 3. Convenient transportation }\end{array}$ & $\begin{array}{l}\text { 2. Short ice age with poor } \\
\text { quality of snow }\end{array}$ \\
\hline
\end{tabular}

TABLE 3 Analysis of foreign competitors in Harbin's development of ice and snow sports tourism

\begin{tabular}{|c|c|c|c|}
\hline $\begin{array}{l}\text { CLASSI } \\
\text { FY }\end{array}$ & Main competitors & advantage & disadvantaged \\
\hline $\begin{array}{l}\text { FOREIG } \\
\mathbf{N}\end{array}$ & Davos, Switzerland & $\begin{array}{l}\text { 1. World-class ice and snow sports } \\
\text { facilities }\end{array}$ & $\begin{array}{l}\text { 1. Cumbersome entry and exit } \\
\text { procedures }\end{array}$ \\
\hline $\begin{array}{l}\text { COMPE } \\
\text { TITORS }\end{array}$ & Hokkaido, Japan & $\begin{array}{l}2 . \\
\text { the advanced management and hig }\end{array}$ & $\begin{array}{l}\text { 2. Easy to produce language and } \\
\text { other communication barriers }\end{array}$ \\
\hline
\end{tabular}

ISSN: 0010-8189

C CONVERTER 2021

www.converter-magazine.info 


\author{
Gangwon, South \\ Korea \\ French Alps
}

h quality service

3. Perfect integrated marketing strategy

4. Relatively low consumer prices

3. Excellent natural conditions and exotic customs

\section{Brand Orientation of Ice-Snow Tourism in the Arctic Village}

Arctic Village of Mohe County locates in the northeast China and it is titled as the "emerald on the gold comb". Arctic Village is a natural village in the northernmost of mainland China and it locates at the south bank of the Heilongjiang River which is the China-Russia Boundary River in Mohe County, Heilongjiang Province $\left(53.5^{\circ} \mathrm{N}\right)$. Due to the unique natural geological position, there's a fantastic astronomical landscape ------ Auroras. Hence, it has the reputation of "Sleepless City". Arctic Village is the northernmost tourism attraction in China ${ }^{[7]}$.

The Arctic Village is not only the sole place for appreciating aurora and north polar lights in Asia, but also the sole Christmas Village in Asia. It is the place of "Santa Claus Takes You Skiing" which is registered by Finland, the place surrounded by negative oxygen ions of forest, the place to understand the son of forest ----- the Oroqen Nationality, and the place to have ice-snow adventures. In a manner of speaking, the brand orientation of the Arctic Village can be summarized as the "uniqueness of Asia and the acme of North".

The author conducted an online survey on the popularity of ice-snow tourism cities, the respondents chose according to their preferences.It can be seen from Figure 1 and figure 2 that the domestic brand competitors ofArctic Village of Mohe County are mainly Shenyang and Changchun, while the foreign brand competitors are mainly Japan and South Korea.Competition among brands of ice and snow tourism can greatly promote the integration of ice and snow resources in Arctic Village of Mohe County and enhance the city's brand image from the perspective of marketing ${ }^{[8]}$.

\section{Domestic brand competitors}

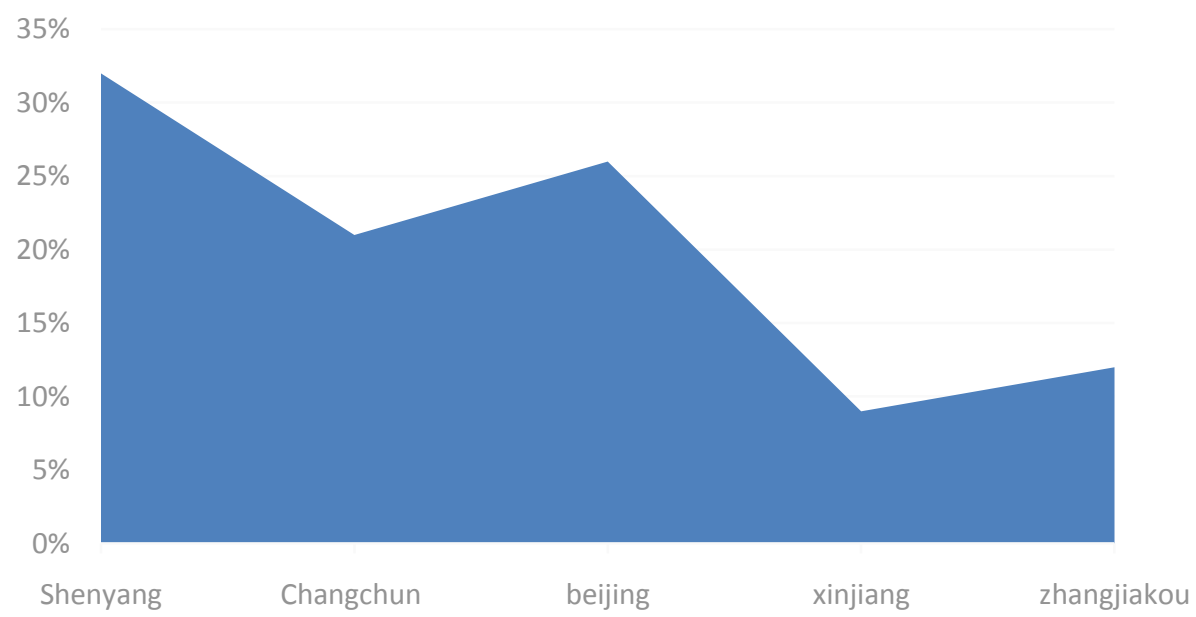

Figure 1: Domestic brand competitors

ISSN: 0010-8189 


\section{Foreign brand competitors}

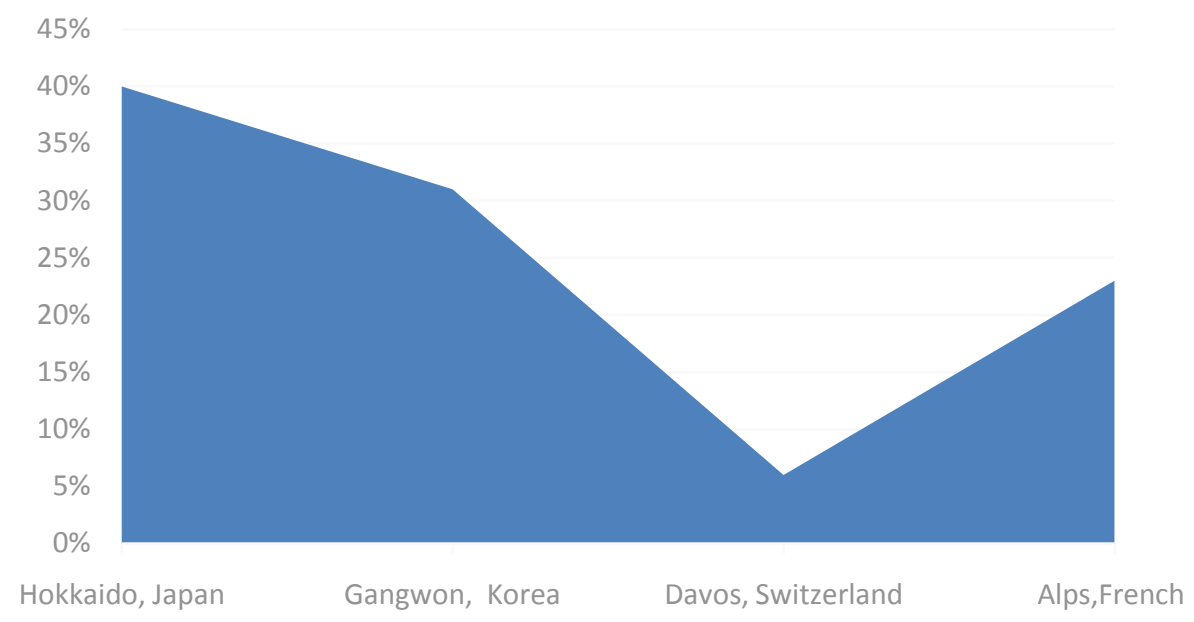

Figure 2: Foreign brand competitors

\section{Problems Existing in Brand Marketing of Arctic Village of Mohe County}

\subsection{Inadequate Marketing Efforts of New Media}

Although Arctic Village of Mohe County possesses abundant ice and snow tourism resources, it still achieves a low reputation as an ice-snow tourism brand. Many tourists view ice-snow and sausage as the tourism brand of Arctic Village of Mohe County. The publicity on its tourism brand has to be strengthened.

The author investigated the ways of tourists to collect tourism information. It can be seen from Figure 3 that most tourists choose new media platforms such as Weibo, short videos and APPS, and the marketing of new media is the key.

\section{The media through which tourists learn about tourism information}

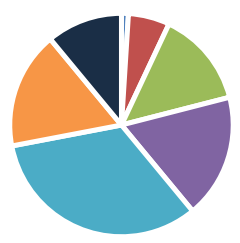

$$
\begin{aligned}
& \text { - The newspaper } \\
& \text { - TV } \\
& \text { - A short video } \\
& \text { - weibo } \\
& \text { - Travel website } \\
& \text { - APP }
\end{aligned}
$$

Figure 3: The media through which tourists learn about tourism information

\subsection{Inadequate Propagation of Cultural Connotations}

For conceptual tourism, experience tourism and innovative tourism, cultural deposits of a city is undoubtedly a measurement standard of its competitiveness. Although Arctic Village of Mohe County is northernmost city with ISSN: 0010-8189 
unique cultural connotations, cultural elements account for a very low proportion in tourism propagation. It is suggested to combine with the ice and snow resources to increase cultural features of ice-snow tourism in Arctic Village of Mohe County.

4.3Inadequate Combination of Snow-Ice Resources and Other Resources

The ice-snow tourism of Arctic Village ofMoheCountygives tourists an impression of cold weather, beautiful snow scenes, but backward economy and no other scenic spots. Hence, only the combination of ice and snow resources with other resources that can bring a coordinated development of industries, promote the ice-snow economic development in Heilongjiang Province and strengthen the regional competitiveness ${ }^{[9]}$.

\section{Ice-snow Tourism Product Planning in the Arctic Village}

Cognitions of Chinese and foreign tourists for the Arctic Village are limited within "northernmost" and "aurora". The concept of "northernmost" has become the primary logo of tourism in Arctic Village. Differently, the brand planning in this study highlights the characteristics of "light" and proposes the tourist-oriented "journey of light searching".

\subsection{Northern lights ------ Natural polar astronomical phenomenon}

Due to the relatively high latitude, Arctic Village experiences polar day $(>17 \mathrm{~h})$ in summer and polar night (daytime $=6 \mathrm{~h}$ ) in winter. As a result, Arctic Village becomes the best place in Asia to observe magical polar lights. This is the unique tourism symbol of the Arctic Village.

The ice-snow tourism of the Arctic Village can make full use of the unique geological advantages to plan and propagate ice-snow activities related with polar region, so that tourists can experience a travel integrating geology, culture, sports and entertainment under extremely cold and polar night conditions.

\subsection{Light of fairy tale ------ the second hometown of Santa Claus}

The Christmas Village and Christmas Ski Resort in the Arctic Village possess a color of fairy tale to some extent. The Christmas Village and the Christmas Village of Finland echo each other at a distance and it is the perfect integration between polar resources of China and western Christmas culture. It is the sole Christmas Village in Asia. Main scenic spots in the Christmas Village include the Santa Claus Office, Santa Claus Post Office, Santa Claus Square, Fairy Tale World, Snow White Land, Reindeer Park, etc. Moreover, there's the sole standardly registered pure Rovaniemi Santa Claus of Finland in Asia. Chinese tourists can experience the original atmosphere of Christmas and taste the cultural feast with significant ice-snow charms in China. The Christmas Ski Resort is the northernmost ski resort in China. It has the longest skiing period and it is equipped with many entertainment facilities to meet tourists' entertainment needs of ice-snow projects, including snowmobile, snow circle, directional sleigh, skiing boat, skis, etc.

The Arctic Village can plan Christmas-themed adventures based on existing resources by combining with atmosphere of Christmas holiday. For example, tourists can issue their Christmas wishes on Weibo and @ the official accounts in one month before the Christmas. During the Christmas holiday, 10 tourists in Arctic Village will be selected and their wishes are realized in the unique way of Santa Claus. Moreover, Christmas gifts are supplied personally. Both parents and children may get a surprise from such experiences and blessing from the Santa Claus in person can strengthen the sense of participations and experiences of tourists.

\subsection{Light of nationality ------ Son of the forest - The brave Oroqen Nationality}

There's a northernmost nationality land in the Arctic Village, which covers an area of 6.7ha. With scenes of

ISSN: 0010-8189

(C) CONVERTER 2021 
production, living and religious sacrifice of northern minorities, such Russia and Oroqen Nationality. The Museum of Oroqen Nationality in the Arctic Village records changes of this brave and mysterious nationality. The Oroqen Nationality originated from and lived in the high Khingan. The Oroqen Nationality lived with natural environment and natural resources, mainly hunting, supported with fishing and collection. Nowadays, although the Oroqen Nationality has walked out of the birch forest and started a life of cultivation and hunting, the brave and persistent spirit as well as the traditional horse riding and hunting techniques are things that tourists cannot experience in other places. Arctic Village is suggested to develop forest horse riding project and a forest stud-farm based on the ice-snow resources to give tourists happiness of horse riding. Tourists can not only return to the mysterious Oroqen Nationality which lived with horse riding, hunting and Khingan, but also experience the traditional winter hunting activities and witness that live fishes are pulled out from the water through small holes and dance on ice. Tourists can participate in the traditional lifestyle of the Oroqen Nationality and witness its history of hunting with a gun, a horse and a hunter in the extensive forest. This can improve cultural connotation of ice-snow tourism in the Arctic Village $^{[10]}$.

\subsection{Light of auspicious snow ------ Romantic ice-snow sports}

There are abundant ice entertainment projects in the Arctic Village, including Mala sleigh, spinning a top on ice, skating, bicycling on ice, etc. Besides, there's an ice lamp garden surrounding spinning top field, where tourists can have fun while appreciating ice lamps. However, these projects are common in other ice-snow tourism regions and have no unique attractions. Therefore, it is necessary to plan new snow projects to highlight the competitive edge of the Arctic Village.

The Arctic Village once held a unique festival of the Snow-Sprinkling Festival. Except for traditional activities like snow sprinkling, Mala sleigh and snow sculpture, there are some local unique activities throughout the festival, such as fishing on ice, sending balloon aloft on ice and having cauldron on ice. Besides, local villagers and the Oroqen Nationality will dress up to celebrate the snow-sprinkling festival with tourists. Based on these traditional ice-snow cultural projects, the Arctic Village has to propagate the Snow-Sprinkling Festival greatly at the theme of "appreciating landscape in polar regions and playing ice-snow games" to highlight its characteristics of internationality, mass, participation and entertainment. Moreover, the brand effect of Arctic Village shall be further explored by developing ice-snow tourism resources and improve the ice-snow cultural tastes. Arctic Village shall make great efforts to improve its reputation and influence by developing characteristic ice-snow tourism projects in the way of government leading, enterprise management, marketing operating and social participation. Based on the Snow-Sprinkling Festival, snow and ice rolling activities are provided. The ice rolling is originated from a legend of the northern ethnic groups: people can get rid of disease, bad luck and disaster by "rolling" on the ice and they can keep a healthy and smooth life throughout a year. These activities can increase cultural color and attract more tourists $^{[11]}$.

\section{Brand communication of ice-snow tourism in the Arctic Village}

\subsection{Strengthen Marketing Efforts Based on New Media}

In brand competition nowadays, it is recommended to strengthen online marketing based on new media continuously in addition to traditional marketing means and integrate relevant resources by using emerging media (e.g. tourism business website, short video platform, Weibo, WeChat, APP and online games) and Internet celebrities. Moreover, the unique advantages of new media, including fast spreading, wide coverage, strong penetration and low cost, shall be developed fully in planning and implementation of a series of promotion activities.

6.2Host ice and snow sports events

China will hold the Winter Olympics in Beijing and Zhangjiakou in 2022, which will bring new opportunities to

ISSN: 0010-8189

C CONVERTER 2021

www.converter-magazine.info 
regions with ice-snow tourism resources in China, especially to ice-snow sports tourism. Mohe County has held many international and national ice-snow sports competitions, such asChina Arctic Mohe Ice and Snow Marathon. These competitions have certain impacts on competitiveness of Heilongjiang Province in ice-snow sports tourism. Moreover, great influences ofOlympic champions and world champions from Heilongjiang, such as Wang Meng, Yang Yang, Wu Dajing, Zhang Kong, Shen Xue, Zhao Hongbo and Wang Bingyu, have some contributions to the competitiveness of Heilongjiang Province in cultural and innovation development of ice-snow sports tourism. Arctic Village of Mohe County and even Heilongjiang Province possess unique ice-snow natural conditions, good site facilities for ice-snow sports, and good basis for public participation in ice-snow sports. Therefore, including ice-snow competitions into tourism plan can make people feel influences of ice-snow sports through tourism experiences, thus driving the ice-snow tourism development.

\subsection{Taking advantage of spreading power of opinion leaders}

Opinion leaders are "activists" who provide others information and affect others in interpersonal communication. They scatter around any social groups and classes. In the era of new media and Internet communication, the Arctic Village can propagate the extreme experiences of its ice-snow tourism in the Mohe County by taking advantages of many information channels, high mass contact frequency and great contact quantity of opinion leaders. This can yield twice the result with half the effort.

\subsection{Propagandize the volunteer alliance through international youth hostels}

It found through a field investigation that the international youth hostels in the Arctic Village have strong local characteristics. Most tourists accommodated in international youth hostels are senior tour pals who are keen with understanding information around the world through communication in the hostels. Based on the volunteer alliance of international youth hostels, Arctic Village can post its ice-snow tourism projects on the message boards of youth hostels around the whole China, develop creativity of the youth, reform the local tourism development mode, and promote its ice-snow tourism based on the curiosity of the youth on new things. These can attract young and regular tourists to the Mohe County.

\subsection{Lunch "Live Broadcasting" to share travelling experiences}

According to the field investigation, hotels, youth hostels, homestays and characteristic restaurants in the Arctic Village have many travelling volunteers who demands for daily meals and accommodation rather than wages. They can experience local life thoroughly in a relatively longer stay and most of them love local places greatly. Therefore, it is suggested that these stores can launch "live broadcasting" to attract attentions of various groups through live propagation of volunteers, experience live broadcasting for tourists and online-offline interactive experiences to meet deep consumption of mass in accordance with their interests and hobbies. Through live broadcasting of the Arctic Village in Mohe County, net friends can understand daily life of local people more intuitively from the first perspective and satisfy their curiosity and desire of exploration. Besides, tourists can interact with net friends actively. Watchers are easier to remember the Arctic Village. Therefore, the reputation of Arctic Village is increased.

\subsection{Advertorial propagation based on We-media}

Arctic Village can collect tourists as the spreader of advertorial propagation based on We-media like Weibo, WeChat and short video platforms. It can strengthen interaction with net pals by sharing travel journeys, further strengthening influences of activities, increase attentions of net pals to the Arctic Village, and improve its brand reputation and influence of ice-snow tourism.

With the development of tourism industry, the original natural scenic spots in the Arctic Village have been damaged and the original landscapes have been changed. Meanwhile, many artificial scenic spots are increased to

ISSN: 0010-8189

(C) CONVERTER 2021 
change travels in the Arctic Village into a "conceptual travel" which concerns the "northernmost" only. Product planning shall be made according to local images and market characteristics to change the single "conceptual travel" into diversified "interesting travels", which endows significant competitiveness to the unique ice-snow tourism in Mohe County.

\section{Acknowledgements}

Supporting Project: Research on Marketing Strategy for Ice-snow Tourism in the Arctic Village of Mohe County under the Perspective of Industrial Integration, Ministry of Education of Heilongjiang Province.(Project No.: 2019-KYYWF-013).

\section{References}

[1] W. Mike, "Sport,Tourism and the Olympic Games:Leveraging Olympic Tourism," pp.2-17,2008.

[2] L. Chen,"Research on Socialized Marketing Strategies for Wulong Tourism Brand in Chongqing,"pp.6-12,2015.

[3] Z.H. Liang,"A Superficial Discussion on Ice-snow Tourism Industrial Development of Heilongjiang Province," no. 2, pp. 117-118,2018.

[4] http://www. hlj.stats. gov. cn/.

[5] H.Y. Ji, Y.L. Xiao, "Development Status of Ice-snow Sports Tourism in Heilongiiang Province and Countermeasures," no. 11, pp. 109-110, 2017.

[6] V. David, H. Lars, "Proterty Rights and Sustainable Nature tourism:Adaptation and Mal-adaptation in Dalamas(Sweden)and Maine (USA)", pp. 224-230, 2000.

[7] http://www. hljtour. gov. cn/.

[8] http://www. hrbicesnow. com/scene.

[9] https://baike.so.com/doc/5346131-5581578.html

[10] Tourism Website of Heilongjiang Province

[11] Tourism Website of Northeast China 